\title{
Word order in heritage Russian: clause type and majority language matter
}

\section{Порядок слов в эритажном русском: влияние типа клаузы и языка окружения}

\author{
Yulia Zuban $^{1} \cdot$ Maria Martynova $^{2}$ (D) Sabine Zerbian ${ }^{1} \cdot$ Luka Szucsich $^{2}$. \\ Natalia Gagarina ${ }^{3}$
}

Accepted: 25 September 2021 / Published online: 8 November 2021

(c) The Author(s) 2021

\begin{abstract}
Heritage speakers (HSs) are known to differ from monolingual speakers in various linguistic domains. The present study focuses on the syntactic properties of monolingual and heritage Russian. Using a corpus of semi-spontaneous spoken and written narratives produced by HSs of Russian residing in the US and Germany, we investigate HSs' word order patterns and compare them to monolingual speakers of Russian from Saint Petersburg. Our results show that the majority language (ML) of HSs as well as the clause type contribute to observed differences in word order patterns between speaker groups. Specifically, HSs in Germany performed similarly to monolingual speakers of Russian while HSs in the US generally produced more SVO and less OVS orders than the speakers of the latter group. Furthermore, HSs in the US produced more SVO orders than both monolingual speakers and HSs in Germany in embedded clauses, but not in main clauses. The results of the study are discussed with the reference to the differences between main and embedded clauses as well as the differences between the MLs of the HSs.
\end{abstract}

\section{Martynova}

maria.martynova@hu-berlin.de

Y. Zuban

yulia.zuban@ifla.uni-stuttgart.de

S. Zerbian

sabine.zerbian@ifla.uni-stuttgart.de

L. Szucsich

luka.szucsich@hu-berlin.de

N. Gagarina

gagarina@leibniz-zas.de

1 Institute of Linguistics, Division of English Linguistics (IfLA), University of Stuttgart, Stuttgart, Germany

2 Department of Slavic and Hungarian Studies, Section of East Slavic Languages, Humboldt University Berlin, Berlin, Germany

3 Research Area 2 'Language Development \& Multilingualism', Leibniz-Centre General Linguistics (ZAS), Berlin, Germany 


\section{Аннотация}

Носители эритажного языка отличаются от носителей, говорящих на языке метрополии, и эти отличия обнаруживаются в различных языковых областях. В данной статье исследуется синтаксис носителей эритажного русского языка. Сравнивается различный порядок слов носителей эритажного русского языка, проживающих в США и Германии, с порядком слов носителей русского языка из Санкт-Петербурга. Настоящая статья опирается на данные корпуса, в состав которого входят семиспонтанные письменные и устные тексты участников эксперимента. Результаты исследования показали, что язык страны, в которой проживают эритажники, а также тип предложения играют роль при использовании определённого порядка слов участниками разных групп. В частности, порядок слов, используемый эритажниками из Германии, не отличался от порядка слов монолингвальных носителей русского языка. Однако в текстах эритажников из США было найдено больше предложений с порядком SVO и меньше предложений с порядком OVS по сравнению с одноязычными носителями русского языка. Кроме того, эритажники из США продемонстрировали бо́льшую частотность порядка SVO по сравнению с эритажниками из Германии и одноязычными носителями русского языка в придаточных предложениях, но не в главных. Результаты исследования интерпретированы со ссылкой на различия между главными и придаточными предложениями, а также на различия между языками официального общения эритажных носителей русского языка.

\section{Theoretical background}

\subsection{Heritage Speakers \& Heritage Russian}

Heritage speakers (HSs) offer an interesting area for linguistic research. These speakers grew up in a multilingual (often bilingual) home and as a result are proficient in several languages. The first language or one of the first languages spoken at home is a heritage language (HL) while the language of the surrounding society is a majority language (ML) (Montrul, 2015, p. 18; cf. among many others Valdés, 2005; Rothman, 2009; Benmamoun et al., 2013; Guijarro-Fuentes \& Schmitz, 2015; Polinsky, 2015). HSs are in many aspects a unique group of speakers since they learn their HL exclusively from their caregivers at home and have nevertheless potential to reach a native-like proficiency level in this language. However, the role of a HL usually decreases dramatically in favor of a ML, acquired simultaneously or subsequently, after entering monolingual educational institutions such as kindergartens and schools. Consequently, a HL acquired as L1 becomes a secondary and a weaker language, and the ML usually becomes the dominant and the most frequently used language of a bilingual individual. Moreover, HSs typically have limited or no command of written mode in their HL since they acquire it mostly by hearing. Some HSs, however, attend language schools where they are also exposed to the written language (cf. Montrul, 2015).

HSs of Russian were found to be extremely heterogeneous regarding their language proficiency, both in Germany (Brehmer, 2007; Anstatt, 2008) and in the US (Polinsky, 2006). This heterogeneity can be also found among different HSs of the same core family (Meng \& Protassova, 2016). Language skills of HSs of Russian were reported to differ from those of the monolingual speakers and those of L2 learners of Russian (Romanova, 2008; Laleko, 2019). Several studies reveal that starting from the second generation of migrants heritage Russian undergoes significant changes in lexicon (Polinsky, 2006; Isurin, 2011; Gagarina, 
2011; Klassert et al., 2014), nominal morphosyntax (Polinsky, 2006, 2008a; Gagarina, 2011; Laleko, 2018), verbal morphology (Romanova, 2008), aspectual system (Gagarina et al., 2020; Polinsky, 2006, 2008b; Anstatt, 2008; Laleko, 2010, 2011, 2015) as well as pro-drop constructions (Isurin, 2011; Dubinina \& Polinsky, 2013) and word order (Polinsky, 2011; Brehmer \& Usanova, 2015; Laleko \& Dubinina, 2018). The present study aims at contributing to the growing research on heritage Russian in the domain of syntax. Specifically, we will examine the word order patterns produced by HSs of Russian residing in the US and Germany.

\subsection{Word order in monolingual Russian, German and English}

Monolingual Russian, German and English differ with respect to the basic word order and effects of information structure on word order. Information structure refers to the "packaging" of information in order to make an utterance fit the immediate communicative needs of interlocutors (Krifka, 2007, p. 13 referring to Chafe, 1976). Russian is considered to be a SVO language in neutral contexts, i.e. with broad focus, in matrix and embedded clauses. Positional permutations are taken to be governed by information structure (cf. Švedova, 2005; Kallestinova, 2007; Slioussar, 2007, 2011; Junghanns \& Zybatow, 2007):
a. Boris
navestil Ivana.
SVO
Boris-Nom visited Ivan-Acc.
'Boris visited Ivan.'
b. Boris Ivana navestil.
SOV
c. Ivana navestil Boris.
OVS
d. Ivana Boris navestil.
OSV
e. Navestil Boris Ivana.
VSO
f. Navestil Ivana Boris.
VOS

(Kallestinova, 2007, p. 1)

The six word order options in (1) are not equivalent regarding their information structure. For instance, (1c) is typically associated with narrow focus ${ }^{1}$ on the subject NP Boris answering a question like "Who visited Ivan?" (1a) is compatible with narrow focus on the object NP (Ivana), with VP focus (navestil Ivana) and with focus on the whole sentence (cf. the literature cited above).

German is a SOV language with V2 in main clauses and reordering options for non-verbal constituents. As for embedded clauses, the finite verb canonically occupies the clause-final position with restricted cases of V2 (cf. Wegener, 1993; Gärtner, 2000; Eppler, 1999; De Vogelaer, 2007; Kempen \& Harbusch, 2019):

(2) [MAIN Das Auto hielt an, [EMBEDDED weil der Ball auf die Straße rollte]]. 'The car stopped because the ball rolled onto the road.'

English, apart from residual V2, is a strict SVO language in both main and embedded clauses with few reordering options (cf. Eppler, 1999; De Vogelaer, 2007; Kempen \& Harbusch, 2019):

\section{(3) The boy dropped the ball.}

\footnotetext{
1 "Focus indicates the presence of alternatives that are relevant for the interpretation of linguistic expressions" (Krifka, 2007, p. 19). Narrow focus typically highlights "the part of an answer that corresponds to the wh-part of a constituent question” (Krifka, 2007, p. 22 referring to Paul, 1880).
} 
Overall, as we have seen, monolingual Russian, German and English show differences in their word order configurations.

\subsection{Word order in heritage Russian}

Word order in HLs was reported to be a phenomenon that is prone to change and transfer from the ML (Polinsky, 2018, p. 273). Moreover, languages that allow multiple word order options show more limited word order patterns in HLs (Polinsky, 2018, p. 273) (cf. studies on word order in different heritage languages cited by Polinsky, 2018, Chap. 6; O'Grady et al., 2011, on heritage Korean; Johannessen \& Laake, 2015, on heritage Norwegian; Cuza, 2012, on heritage Spanish; Fenyvesi, 2005, on heritage Hungarian). We will concentrate on the studies that deal with word order in heritage Russian.

Studies on word order of HSs of Russian in Germany are scarce. The study by Brehmer and Usanova (2015) tested 20 HSs of Russian residing in Germany (mean age of 15.35) and age-matched monolingual Russian speakers. However, the sample used in the study was rather heterogeneous regarding the $\mathrm{AoO}$ of majority German and instruction in Russian, since only 6 HSs in the sample were born in Germany, 10 HSs migrated to Germany before having entered school (mean age upon arrival 4.7), and 4 participants have already attended school in the countries of their origin (mean age upon arrival 10.5). HSs, who were not born in Germany, migrated there from the countries of the former USSR. The production data were collected using written tasks with register differentiation aiming at eliciting academic texts and texts with narrative elements. The findings revealed that HSs did not produce significantly more V2 structures in main clauses compared to the monolinguals. Besides, it was found that HSs did not show less varied word order patterns than monolinguals. On the contrary, HSs produced even more different word order combinations than monolingual speakers, i.e., both speaker groups produced SV, VS, OV, VO, SVO and OSV orders, OVS was only found in the data of monolingual speakers while SOV and VOS orders were only attested in the data of HSs (Brehmer \& Usanova, 2015, pp. 177-178). As for the V-final word orders, in embedded clauses HSs produced significantly more V-final linearizations than monolinguals in texts involving narrative elements (formal texts did not differ across speaker groups) (Brehmer \& Usanova, 2015, p. 179). In main clauses, HSs also produced V-final orders significantly more frequently than monolingual speakers (for main clauses the split according to different tasks was not made) (Brehmer \& Usanova, 2015, p. 180).

Brehmer and Usanova (2015, p. 181) raise a question whether the word order patterns produced by HSs are contextually felicitous since there are some indications in their data that this is not always the case. Take a look at the following example from Brehmer and Usanova (2015, p. 176) in which the verb was placed at the right edge of a clause:
emu
o našem
teste
bumeranga
we
he-DAT.SG.M. about our-LOC.SG.M. test-LOC.SG.M. boomerang-GEN.SG.M.
rasskazali.
tell-3.PL.PST.
'We told him about our testing of the boomerang.'

In example (4), the verb rasskazali 'told' is placed clause-finally, which is unexpected regarding the information structure since the verb receives the main prominence which is not required in the current context. Brehmer and Usanova (2015) suggest that the PP "about our testing of the boomerang" is rather new information here and is expected to appear clausefinally. 
The results of the V-final placement in embedded clauses are explained by potential transfer from the ML. The results of the V-final placement in main clauses are explained with reference to pragmatic unmarking, i.e., V-final orders are "marked" in Standard Russian since they have a restricted range of use. However, V-final orders were produced by HSs more frequently than by monolinguals in a wider range of contexts implying that V-final linearizations became "less marked" for HSs.

Studies on word order of HSs of Russian in the US generally report on the increase of the SVO order use and the reduction of word order flexibility in productions of HSs.

Laleko and Dubinina (2018) studied the distribution of word order patterns in oral narratives of 21 HSs of Russian in the US (mean age of 19.4) and 19 monolingual speakers of Russian (mean age of 23.2). However, only 3 HSs in the participant sample were born in the US in Russian-speaking families, one HS was born in Israel, other HSs were born in countries of the former Soviet Union. HSs, who were not born in the US, migrated there before having reached the school age. Regarding the type of bilingualism, three HSs were simultaneous bilinguals (two HSs with dominant Russian and one HS with dominant English), other participants were mostly sequential and child bilinguals with mean AoO for their ML English of 5.3. The production data were elicited using the methodology by Berman and Slobin (1994) with the wordless book "Frog, where are you?" by Mayer (1969). Following Bailyn (2002, 2004), the authors label SVO word order pattern as basic and word order patterns with inversion (e.g. OVS) and dislocation (e.g. OSV) as non-basic. The findings revealed that HSs showed a reduction of word order flexibility and used more basic SVO word orders $(71.15 \%)$ compared to monolinguals (64.91\%). Similar to monolinguals, HSs produced more word order patterns with dislocation than inversion, however, unlike monolinguals, HSs did not always use them felicitously regarding the requirements of information structure. Below are the examples with dislocation that were identified contextually infelicitous by Laleko and Dubinina (2018, p. 204):

$$
\begin{aligned}
& \text { \#V reku oni upali } \\
& \text { into river-ACC they-NOM fell } \\
& \text { 'Into the river, they fell' } \\
& \text { (cf. Oni upali v reku) }
\end{aligned}
$$

Example (5) is contextually inappropriate since river was introduced for the first time and is expected to occur clause-finally.

$$
\begin{aligned}
& \text { \#On iščet } \underline{\mathrm{v} \text { botinkax }} \text { ljagušku } \\
& \text { he-NOM looking in boots-PREP frog-ACC } \\
& \text { 'He is looking, in the boots, for the frog' } \\
& \text { (cf. On iščet ljagušku v botinkax) }
\end{aligned}
$$

Example (6) is contextually inappropriate since the location in the boots was introduced for the first time and is expected to occur clause-finally.

Polinsky (2006) carried out a study on incomplete Russian by 21 HSs residing in the US. All the participants moved to the US from the countries of the former Soviet Union at the age between three and 11 years (mean age upon arrival 6.8) and stayed in the host country for 9 to 21 years (mean of 14) before the beginning of the study. The data were collected through interviews and a lexical test was used to assess HSs' proficiency. Polinsky (2006, p. 237) tentatively reported that HSs of Russian in the US produced SVO order as the most predominant one with both nominal and pronominal arguments. In Standard Russian, however, the order SOV is often expected for pronominal arguments.

Isurin and Ivanova-Sullivan (2008) conducted an experimental study aiming at comparing the linguistic performance of HSs of Russian with that of monolinguals and L2 learners of 
Russian. The participants' sample comprised three populations matched on age, social, and educational background: 7 HSs of Russian, 11 advanced learners of Russian with L1 English and 5 monolingual Russian speakers as a control group. However, in addition to the HSs who were born in the U.S. in Russian-speaking families, the HSs group also consisted of immigrants from the former USSR, arriving to the US before the age of 10. Crucially, the authors do not provide any further information on the composition of the HSs group. The production data were collected using the methodology by Berman and Slobin (1994) with the picture book "A boy, a dog, a frog and a friend" by Mayer and Mayer (1978) with one modification, i.e., the participants were asked not to look through the entire book prior to the storytelling, in contrast to the original methodology. The authors found that HSs of Russian in the US used VS orders more frequently than L2 learners of Russian, but less frequently than monolingual speakers of Russian. These results could be either interpreted as a language transfer from the ML or "as a solution to the higher cognitive load of a VS sentence" (Isurin \& Ivanova-Sullivan, 2008, p. 100).

Isurin (2005) investigated possible language transfer of word order from majority English into heritage Russian in a longitudinal study of one Russian girl adopted by a family in the US at the age of nine. The study included different tasks such as picture description, semispontaneous conversation, and storytelling and stretched over 13 months. The child was shown the same picture or had to retell the same story within an interval of nine months between the sessions. The results of the picture description task showed that the participant increased the frequency of SVO orders in the later session compared to the earlier session. Besides, the participant did not show any XVS orders (X stands for indirect objects, adverbial modifiers, etc.) in the second session whereas this order was still present during the first session (Isurin, 2005, p. 1121). As for the storytelling task, the results revealed that the participant did not produce any orders with inversion (that are frequent for storytelling in Standard Russian) in the second session while inverted orders such as VS and VSX were present during the first session (Isurin, 2005, p. 1122). Isurin (2005, p. 1122) gives two possible interpretations of the results. One possible reason for the absence of inversion in the later session and an increase of SVO order can be due to transfer from the ML. Another possible explanation of the results relates to language-internal factors. Specifically, the word order that is less frequent in the HL was replaced by the more frequent word order (i.e., SVO) which was still compatible with the information structural requirements.

Kisselev (2019) examined the word order patterns in written texts of 23 HSs of Russian, 22 less proficient L2 learners of Russian and 22 more proficient L2 learners of Russian, as well as of 17 monolingual speakers of Russian, who either lived in Russia at the moment of testing or recently arrived in the US. The HSs group consisted of participants who were either born in the US or had migrated there before the age of six. No further information on the composition of the HSs group were provided by the author. The production data of HSs and L2 learners were drawn from an essay corpus of annual American Council of Teachers of Russian National Post-Secondary Russian Essay Contest. Essays by monolinguals were collected by the author. The essays across all groups had the same topic. The results of the study revealed that both L2 learners and HSs produced more SV-patterns than monolingual speakers. Moreover, both L2 learners and HSs produced less VS-patterns compared to monolinguals. $^{2}$

HSs were also often found to differ from monolingual speakers in the domain of inflectional morphology (cf. Polinsky, 2018, for a detailed overview). Interestingly, some studies

\footnotetext{
${ }^{2}$ It has to be noted that the SV-patterns mentioned by Kisselev (2019) are not only those of SV(O), but all patterns in which the verb follows the subject (i.e., SVO, SV, SOV, OSV). VS-patterns are those in which the subject follows the verb (OVS, VS, VOS, VSO).
} 
report that there is a connection between the HSs' knowledge of inflectional morphology and word order. Montrul (2015, p. 71) states that "the simplification of case and agreement morphology characteristic of many heritage language grammars has consequences for the basic clause structure and for pronominal reference." (cf. studies on word order in different heritage languages cited by Montrul, 2015, pp. 71-72: Montrul, 2010a, 2010b, for heritage Spanish; Montrul et al., 2015, for in heritage Spanish and Romanian; Albirini et al., 2011, for heritage Egyptian; Song et al., 1997, for heritage Korean).

The connection between inflectional morphology and word order has also been made for heritage Russian. As for the production of word order, Sussex (2002, p. 1020) found the decline of word order variation in émigré Slavonic languages that to some extent correlates with the decline of case inflections. Slavonic languages permit great word order variation by virtue of the rich inflectional systems (with exception of Bulgarian and Macedonian that lost the nominal cases). Thus, the decline in the case inflections will make it difficult to distinguish grammatical relations and as a result the SVO order will become the dominant one. Sussex (2002, p. 1020) further reports that SVO order is more frequent among the first-generation Slavonic émigré compared to the monolingual homeland speakers and it is the dominant word order of HSs of Slavonic.

The connection between inflectional morphology and word order has also been made in perception studies. For instance, Polinsky (2011) investigated the comprehension of subject and object relative clauses by HSs of Russian in the US and monolingual speakers of Russian. The speakers belonged to two age groups: children and adults. The results of the study revealed that children of both speaker groups behaved similarly to each other while adult HSs differed from the adult monolinguals. Specifically, adult HSs showed significantly weaker results than adult monolinguals in interpretation of object relative clauses, but not subject relative clauses. The findings of the study were interpreted as language attrition. Polinsky (2011) further points out that attrition can be explained by the presumed insensitivity of HSs to case morphology that helps monolingual speakers identify how participants relate to each other in the story. If HSs do not rely on case morphology, "the universal preference for subject relative interpretation kicks in, causing heritage speakers to perform perfectly on subject relatives and at chance on object relatives" (Polinsky, 2018, p. 246). Although Polinsky (2011) did not explicitly measure case attrition and word order the results of the study (as interpreted by Polinsky, 2011) point to a possible connection between the presumed insensitivity of HSs to case morphology and the interpretation of the word order patterns.

Overall, HSs in Germany were found to show a high degree of word order variation in their HL. HSs in Germany were further found to be similar to monolingual speakers regarding some aspects of word order (V2 structures in main clauses), but the former differed from the latter regarding some other aspects (V-final word orders in embedded and main clauses) (Brehmer \& Usanova, 2015). HSs in the US, on the other hand, were typically found to increase the use of the SVO order and show a less flexible word order than monolingual speakers (Laleko \& Dubinina, 2018; Polinsky, 2006; Isurin \& Ivanova-Sullivan, 2008; Isurin, 2005). Some studies further assume a connection between inflectional morphology and word order such that the decline in word order variation may correspond to the decline in case inflections (Sussex, 2002; Polinsky, 2011).

\section{Research questions and predictions}

Taking the aforementioned studies on word order of HSs of Russian into account, we would like to contribute to the understanding, whether word order patterns are subject to change 
(due to transfer from the MLs or due to some general language change mechanisms in contact situations). The current study aims at answering the following research question:

RQ: Are the word order patterns produced by HSs of Russian residing in the US and Germany different from those of monolingual speakers of Russian? ${ }^{3}$

Prediction 1: We expect that HSs in Germany will differ from monolinguals regarding the overall word order patterns by producing more V-final linearizations in both main and embedded clauses (see Brehmer \& Usanova, 2015).

Prediction 2: We expect that HSs in the US will differ from monolinguals regarding the overall word order patterns by producing more SVO orders (Laleko \& Dubinina, 2018; Polinsky, 2006; Isurin \& Ivanova-Sullivan, 2008; Sussex, 2002; Isurin, 2005).

\section{Study design}

\subsection{Stimuli and procedure}

The data were collected within the research project "Emerging Grammars in Language Contact Situations" that looks into the linguistic systems of HSs and aged-matched monolinguals of different languages in the US, Germany and the respective countries of origin, incl. Russia. The semi-spontaneous data for the current study were elicited using the Language Situations method that allows to elicit naturalistic data in different set-ups (Wiese, 2020). Participants were presented with a video of a fictional car accident and they were asked to narrate what they saw in four communicative situations that differed regarding formality (formal vs informal) and mode (spoken vs written). Each elicitation involved two elicitors: one for the formal and one for the informal situations. In the formal situations, the elicitor was dressed up formally in a suit and met the participant in a room that looked formal like an office. In informal situations, the elicitor was dressed up casually in jeans and a T-shirt, met the participants in another room, and offered the participant some beverages and snacks. Also, the "formal elicitor" dealt with organizational issues (consent-forms, receipts, information about the study), addressed participants formally (e.g. the formal form of 'you' in Russian was used). In contrast, the "informal elicitor" behaved informally and used vernacular language (e.g., informal greetings such as privet 'hi'). Besides, the informal part of the study was accompanied by a 10-15 minutes chit-chat to create a relaxed atmosphere before the elicitation (for the full description of the method see Wiese, 2020). Bilingual participants were recorded in their ML and HL in two separate sessions with mother tongue elicitors which took place at least three days apart. In this article we will concentrate on the productions in Russian.

\subsection{Participants}

The data for the current study consist of 96 narrations, produced by 24 age- and gendermatched speakers (4 narrations per speaker) of the following speaker groups:

- HSs of Russian with MLAmerican English (N=8, mean age=15.7, $\mathrm{SD}=1.51$, four females)

\footnotetext{
${ }^{3}$ Word order patterns refer to the frequency of a particular word order.
} 
- HSs of Russian with ML German ( $\mathrm{N}=8$, mean age $=17.0, \mathrm{SD}=0.84$, four females)

- Monolingual Russian speakers ( $\mathrm{N}=8$, mean age $=16.6, \mathrm{SD}=0.49$, four females)

The data collection took place in the greater Washington area (Virginia, Maryland), in Berlin and Saint Petersburg, respectively. All participants filled out a background questionnaire after the study. Almost all HSs in this study were born in the US or Germany (one participant from each HS group was born in Russia and came to Germany or the US at the age of four and six, respectively).

All HSs were exposed to Russian from birth at home. ${ }^{4}$ Specifically, it was crucial that participants spoke Russian at home on a daily basis with at least one of their caregivers. Also, the families in which Russian was not spoken by all caregivers were included in the study. Additionally, Russian was learned in a formal school setting by some HSs. One HS in the US studied Russian in a language school for 6 years while five HSs in Germany learned Russian in school or in a language school (two HSs learned it for four years, two other HSs spent five years learning Russian, and one HS learned Russian for 12 years). Four HSs in the US and two HSs in Germany additionally had some free time activities in Russian such as gymnastics, piano or music lessons, dance classes. If all the activities involving Russian are counted together (Russian learning and hobbies in Russian), six HSs in Germany and five HSs in the US took part in some activities in Russian. Almost all HSs could write in Russian Cyrillic script (all HSs in Germany and seven HSs in the US). In sum, the participants in both HSs groups are rather homogeneous regarding the AoO in L1 Russian and the language background in Russian. Although HSs in Germany may have more exposure to the formal education in Russian than those in the US.

As for the ML, three HSs in the US and three HSs in Germany started acquiring English or German from birth or at the age of 24 months at the latest, while three HSs in the US and five HSs in Germany reported to have started learning the ML at the age of 48 months at the latest. Also, two HSs in the US started acquiring their ML between the age of five and seven years. On average HSs in the US started learning their ML at the age of 4.2 while HSs in Germany did so at the age of 3.1 .

All participants filled out a questionnaire about their language skills in Russian in four language domains: understanding, speaking, reading, and writing. Participants were asked to assess their Russian language skills by answering the following question: How easy do you find it to understand spoken/speak/read/write (in) Russian: very easy, easy, neither easy nor difficult, difficult, very difficult. Participants' answers were transformed into scores on a scale from 0 to 1 where 0 is "very difficult" and 1 is "very easy". The average scores for all four language domains are the following: 0,82 for HSs in the US, 0,77 for HSs in Germany, and 0,92 for monolingual speakers. It can be seen that all speaker groups find it easy or very easy to use Russian. As expected, the score of monolingual speakers was higher than the one by HSs of both groups. The score of HSs in the US was slightly higher than the one by HSs in Germany. As for the scores of participants per domain, they are summarized in Table 1.

It can be seen that all speaker groups have the same score for understanding whereas the scores of HSs of both groups are lower than the ones of monolingual speakers in all other language domains. Writing received the lowest score compared to the other three language domains by all speaker groups (but especially by HSs in Germany).

\footnotetext{
${ }^{4}$ One HS in Germany reported to have started acquiring Russian at the age of three, but we know from the questionnaires that both parents speak exclusively Russian at home, as reported by the same HS. Thus, we assume that the question about the start of acquiring Russian could be misunderstood as a question about the start of the first utterances in Russian. One HS in the US reported to have started acquiring Russian at the age of 10 months. Here again, we assume that the question about the start of acquiring Russian could be misunderstood as a question about the start of the first words in Russian.
} 
Table 1 Average scores of language skills in four domains in Russian

\begin{tabular}{lllll}
\hline & understanding & speaking & reading & writing \\
\hline HSs_US & 0,94 & 0,81 & 0,78 & 0,75 \\
HSs_Germany & 0,94 & 0,84 & 0,75 & 0,56 \\
Monolinguals & 0,94 & 0,94 & 0,97 & 0,84 \\
\hline
\end{tabular}

Table 2 Average scores of media use in Russian

\begin{tabular}{lllll}
\hline & video & audio & writing & reading \\
\hline HSs_US & 0,63 & 0,56 & 0,75 & 0,56 \\
HSs_Germany & 0,56 & 0,63 & 0,69 & 0,56 \\
Monolinguals & 0,94 & 0,94 & 1 & 1 \\
\hline
\end{tabular}

\begin{tabular}{lllll}
\hline & video & audio & writing & reading \\
\hline HSs_US & 0,94 & 0,88 & 1 & 0,75 \\
HSs_Germany & 0,81 & 0,56 & 1 & 0,94 \\
\hline
\end{tabular}

Table 3 Average scores of media use in majority languages

Next to the self-assessment in language skills HSs were asked how often they used different types of media in Russian: video (movies on TV or online), audio (radio, music, and audiobooks), writing (e-mails, WhatsApp messages, SMS), reading (books, magazines, blogs). Participants were asked about the frequency of their media use: often, sometimes, never. The answers were transformed into scores where 0 stands for "never" and 1 stands for "often".

The average scores for all four language domains are summarized as follows: 0,63 for HSs in the US, 0,61 for HSs in Germany, and 0,97 for monolingual speakers. It can be seen than monolinguals often use different types of media in Russian while HSs tend to do so rather sometimes than often. The scores for the exact medium are summarized in Table 2. It can be seen that writing received higher scores by both HS groups compared to the other media.

The scores for the media use in the MLs of HSs differ from those in their HLs. Specifically, HSs in the US showed an average score of 0,89 for the use of media in English while HSs in Germany showed an average score of 0,83 for the use of media in German. The scores for the exact medium are summarized in Table 3. It can be seen that HSs use different types of media more often in their MLs than in their HLs, suggesting that they use their MLs English and German as their primary languages in daily life. Interestingly, HSs in Germany report to use the medium audio more frequently in Russian than in German. ${ }^{5}$

Regarding the use of the heritage and majority languages in their core families HSs were asked to indicate which languages they choose in daily conversations with each of their parents and in which languages they are usually addressed by each of them. The participants' answers were transformed into scores on a scale from 0 to 1 , where 0 is "majority language", 0,5 is "majority and heritage language" and 1 is "heritage language". The scores were summarized as one overall score. If HSs exclusively used their HL at home, their maximum

\footnotetext{
${ }^{5}$ However, in contrast to the US group, HSs in Germany may use media in a language other than Russian or German, namely English, which is widespread in the German media of all kinds.
} 
Table 4 Average scores of language use in bilingual homes

\begin{tabular}{lllll}
\hline & I to my mother & my mother to me & I to my father & my father to me \\
\hline HSs_US & 0,69 & 0,75 & 0,69 & 0,75 \\
HSs_Germany & 0,88 & 0,94 & 0,58 & 0,67 \\
\hline
\end{tabular}

Table 5 Participants' code

\begin{tabular}{ll}
\hline Code & Meaning \\
\hline RU, DE, US & Country of elicitation: Russia, Germany, USA \\
mo, bi & Mode of language acquisition: monolingual, bilingual \\
$01-99$ & Participants' number \\
F, M & Gender: female, male \\
R & Heritage language or, for monolinguals, their only language: Russian \\
fs & Mode of elicitation: formal spoken \\
fw & Mode of elicitation: formal written \\
is & Mode of elicitation: informal spoken \\
iw & Mode of elicitation: informal written \\
$\mathrm{R}$ & Language of elicitation: Russian \\
\hline
\end{tabular}

score reached 4 (4 HSs in the US and 5 HSs in Germany). If HSs exclusively used their ML at home, their score was 0 (one HS in the US). In families with only one caregiver (two single mothers in HSs in Germany), the scores for the single caregivers were counted two times. The overall average scores are the following: 2,88 for HSs in the US, and 3,25 for HSs in Germany, demonstrating that HSs in Germany are exposed to Russian at home to a higher degree than HSs in the US. The average scores for each question point are provided in Table 4. It can be seen that parents use heritage Russian when addressing their children more frequently than vice versa. Interestingly, mothers of HSs in Germany seem to speak Russian more often to their children, than other caregivers across all groups.

\subsection{Data analysis}

The elicited data were transcribed and anonymized. Table 5 provides an overview of the code assigned to the participants' production.

The data were extracted from the RUEG-RU_0.3.0 corpus (Wiese et al., 2019) into an Excel data-sheet and consequently analyzed in R (R Core Team, 2020).

The Russian language knowledge level was not formally measured during the experiment. In order to see how participants performed in Russian, we annotated their innovations in the domain of morphology and lexicon using the classification given in the Russian Learner Corpus (Rakhilina et al., 2016). The classification includes a set of different tags for the annotation of innovations in the domains of orthography (e.g., Graph for the annotation of mixing-up of the Cyrillic and Latin alphabets within a single token), morphology (e.g., Infl for the annotation of the use of an inflection that is not present in the paradigm of a given lemma), syntax (e.g., Passive for the annotation of the non-monolingual like use of a passive form), lexicon (e.g., $C S$ for the annotation of code-switching), as well as an extra set of tags for the annotation of complex innovative phenomena (e.g., Miss for the annotation of a missing element, such as a letter or a token). 


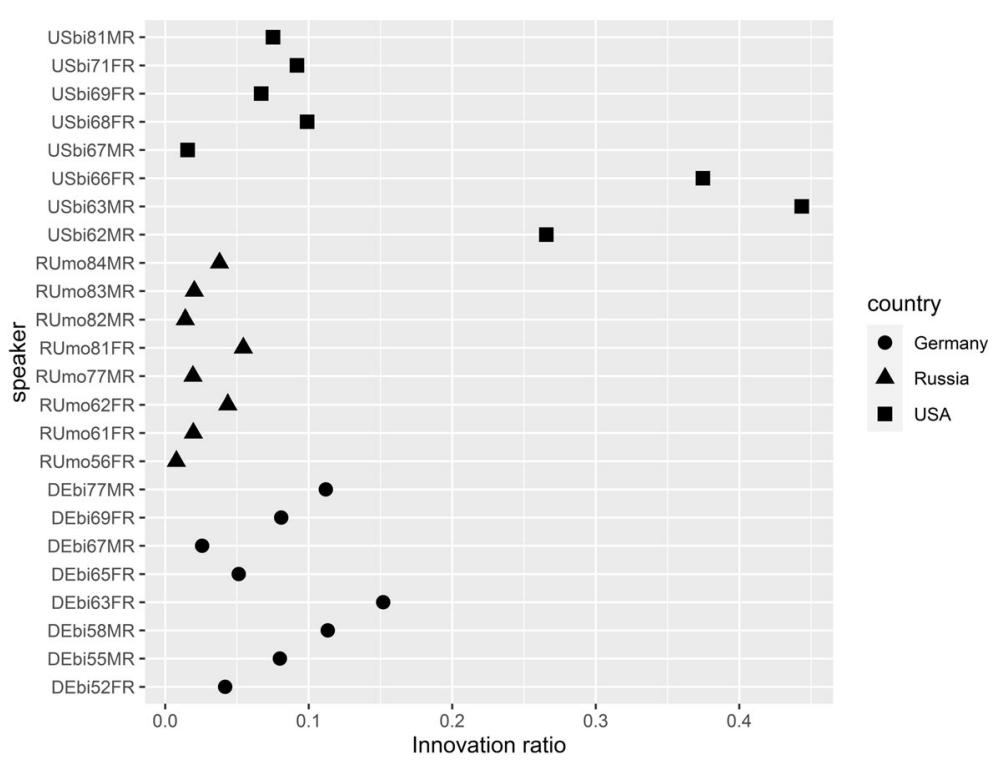

Fig. 1 Innovation ratio of speakers

For each speaker, an individual innovation ratio value was calculated. For this purpose, the total number of innovations produced by one speaker was divided by the total number of words produced by this speaker. Figure 1 illustrates individual innovation ratio values of each speaker. The higher the innovation ratio of a speaker, the lower his or her language performance.

It can be seen that overall monolingual speakers achieved higher language performance (lower innovation values) compared to the HSs. Moreover, monolingual speakers showed innovation scores that compactly lie within the range of 0,01 to 0,05 . In contrast HSs showed greater variation regarding the innovation scores compared to monolinguals (HSs in the US: from 0,02 to 0,44 ; HSs in Germany: from 0,03 to 0,15 ). Some HSs showed ratio values lying quite close to those of monolinguals (e.g., USbi67MR, DEbi67MR, DEbi65FR, DEbi52FR). However, the majority of HSs showed innovation scores within 0,05 and 0,16 and these scores were greater than the ones of monolingual speakers. Also three HSs in the US showed innovation scores that were much greater than the scores of all other participants (USbi62MR, USbi66FR, USbi63MR).

Additionally to innovations in the domain of morphology and lexicon, the data were manually annotated for syntactic functions and included the following annotation layers: clause type, verb type, and word order pattern. Incomprehensible material, unfinished and incomplete utterances were not annotated and excluded from the analysis.

\section{- Clause type}

96 narrations had to be manually annotated for word order, i.e., manually extracted from the RUEG corpus, put into an Excel table, split into clauses and different word order types. The annotations of word order were done by the first two authors of the article and cases where the annotators did not agree were further discussed.

1784 utterances resulting out of the 96 narrations were tagged with a suitable clause type tag for either a main or an embedded clause. Due to a special syntactic status (i.e., rather fixed 
word order) of the most common possessive construction with preposition $u$ 'at, close to' + $\mathrm{NP}_{\mathrm{GEN}}+$ verb byt' / est' 'be' in Russian (see e.g., Weiss \& Raxilina, 2002), the possessive constructions were excluded from the analysis.

- Verb type

For the annotation of the verb type the following tags were used: analytical (finite verb controlling its verbal argument), auxiliary, copula, finite, gerund, infinitive, modal, participle, verbless.

\section{- Word order patterns}

For the annotation of the word order patterns the following tags were used: O (direct object), Oobl (oblique and indirect object), Orel (relativizer which is an object), pred (predicate), proV (subject pro drop), S (subject), Sobl (oblique subject), Srel (relativizer which is a subject), Srelobl (relativizer which is an oblique subject), V (verb).

Subjects involved into VP coordination, which were not lexically realized in the subsequent VP coordination clauses, were annotated as oblique subjects (Sobl) in relevant coordinated clauses. Oblique objects (Oobl) were indirect objects or PP arguments, as the example 7 below shows:

$\begin{array}{llllll}\text { Sobaka čerez dorogu uvidela ètot mjač } & \text { i } & \text { pomčalas' } & \text { zanim. } \\ \text { dog across street } & \text { saw } & \text { this ball } & \text { and } & \begin{array}{l}\text { ran } \\ \text { after.it }\end{array} \\ \text { S } & \text { V } & \text { O } & & \text { SoblV } & \text { Oobl }\end{array}$

'The/A dog from across the street saw this ball and ran after it.' (USbi63MR_fwR)

For 1404 declarative clauses containing a finite verb an applicable word order pattern was annotated. Clauses with gerunds, infinitives, participles, and without verbs were excluded from the analysis since they do not allow to determine a word order pattern including the three component $\mathrm{S}, \mathrm{V}$, and $\mathrm{O}$. The first three verb forms are non-finite, i.e. they systematically lack a subject.

For the further analysis, only trivalent word order patterns containing a non-oblique subject, a finite verb, and an object (both direct and oblique) were chosen and subsequently formed the 6 default word order patterns (783):

- SVO, SrelVO, SrelVOobl, SVOobl $\rightarrow$ SVO (501)

- OVS, OoblVS, OrelVS $\rightarrow$ OVS (142)

- SOV, SOoblV, SrelOoblV $\rightarrow$ SOV (71)

- OSV, OoblSV, OrelSV $\rightarrow$ OSV (47)

- VSOobl $\rightarrow$ VSO (15)

- VOoblS $\rightarrow$ VOS (7)

\section{Results}

In what follows the results of the study will be presented. First, we will concentrate on the results of the overall distribution of different word order patterns without splitting the clauses into main and embedded ones. Second, the results for the main and embedded clauses will be discussed.

\subsection{Overall word order distribution}

The absolute frequencies of default word order patterns are shown in Table 6. Figure 2 shows the distribution of different word orders (\%) across the three speaker groups and all clause 
Table 6 Overall number of the finite clauses

\begin{tabular}{ll}
\hline Groups & Number of finite clauses \\
\hline HSs_US & 268 \\
HSs_Germany & 303 \\
Monolinguals & 212
\end{tabular}

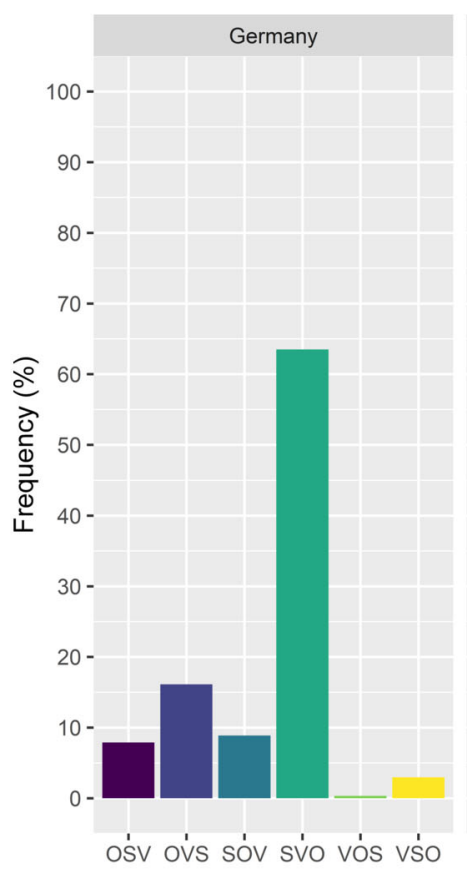

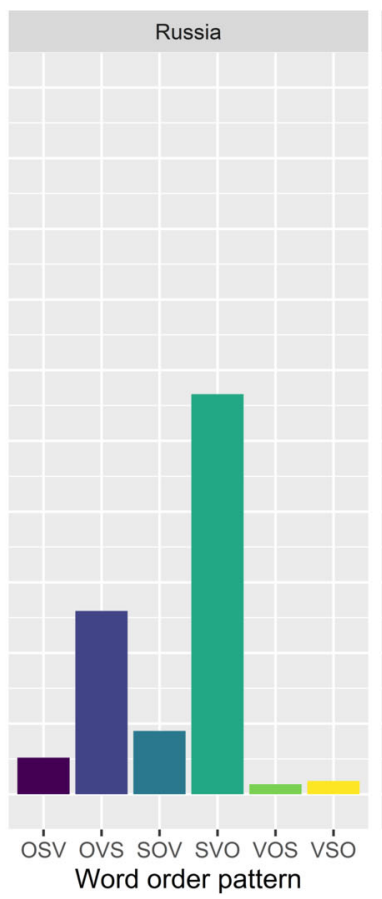

Fig. 2 Default word order patterns

types. The word order was counted from all finite clauses that consisted of three components with overt subjects and direct and/or oblique objects, as stated in Chap. 3. In what follows (Fig. 3 and Fig. 4) the distribution of word order was counted similarly. It can be seen that all three groups have a similar word order distribution, i.e., SVO order is the most frequent one followed by OVS and SOV. The other three word orders are rather infrequent in the data of all speaker groups (except for OSV that is nearly as frequent as SOV in the productions of HSs in Germany).

A careful comparison of the overall word order distribution, however, reveals that not all the groups are statistically similar to each other. The distribution of the overall word order was similar between HSs of the two groups and between HSs in Germany and monolinguals, but it was significantly different between HSs in the US and monolinguals $\left(X^{2}(4, \mathrm{~N}=480)=\right.$ 12.96, $p=.011){ }^{6}$ In order to find out where the difference between the HSs in the US and monolinguals lies, we examined the distribution of each word order produced by these two

\footnotetext{
${ }^{6}$ VOS and VSO orders had to be added together since each of them separately did not have enough instances to perform a significance test.
} 
Table 7 Overall number of six default word order patterns in main clauses

\begin{tabular}{ll}
\hline Groups & Number of finite clauses \\
\hline HSs_US & 215 \\
HSs_Germany & 215 \\
Monolinguals & 178 \\
\hline
\end{tabular}

speaker groups. Distribution of a particular word order was investigated relative to all other word orders.

We found that HSs in the US significantly differed from monolingual speakers regarding the distribution of two word orders, namely SVO and OVS. Specifically, HSs in the US produced significantly more SVO orders than monolinguals $\left(X^{2}(1, \mathrm{~N}=480)=9.45, p=.002\right)$. Moreover, HSs in the US produced significantly less OVS orders compared to monolingual speakers $\left(X^{2}(1, \mathrm{~N}=480)=10.49, p=.001\right)$. As for the word orders with dislocation, namely SOV, OSV, and verb-initial orders, their distribution was found to be similar between these speaker groups.

As far as the verb-final word orders are concerned (i.e., SOV and OSV grouped together) their distribution did not significantly differ across speaker groups.

To sum up, the distribution of different word orders was found to be similar between HSs of both groups and between HSs in Germany and monolingual speakers. However, HSs in the US significantly differed from monolinguals regarding the distribution of SVO and OVS orders.

\subsection{Word order distribution in main and embedded clauses}

\subsubsection{Word order distribution in main clauses}

A closer look at main versus embedded clauses reveals interesting findings. We will start by looking at the main clauses. Table 7 shows the absolute frequencies of default word order patterns in main clauses.

Figure 3 shows the distribution of different word order patterns (\%) across the three speaker groups in main clauses. The SVO order was again the most frequent one across the speakers of all groups, followed by OVS, SOV and the other word orders. Monolinguals produced less SVO orders than HSs of both groups. Moreover, monolingual speakers produced more OVS orders compared to HSs of both groups. However, none of the numerical differences was found to be statistically significant, i.e., all three groups behaved similarly to each other regarding the overall distribution of different word orders in main clauses. As far as the verb-final word orders are concerned (i.e., SOV and OSV grouped together) their distribution was similar across speaker groups.

\subsubsection{Word order distribution in embedded clauses}

Let's take a look at the distribution of different word orders in embedded clauses across the three speaker groups.

Figure 4 displays the distribution of different word order patterns in embedded clauses (\%) across the three speaker groups. It can be seen that the SVO order is again the most frequent one across speakers of all groups. Interestingly, the frequency of SVO increased for all speaker groups compared to the main clauses, but to a different extent. HSs in Germany showed a slight increase of SVO orders $(64,1 \%$ in embedded clause vs. $63,3 \%$ in main 


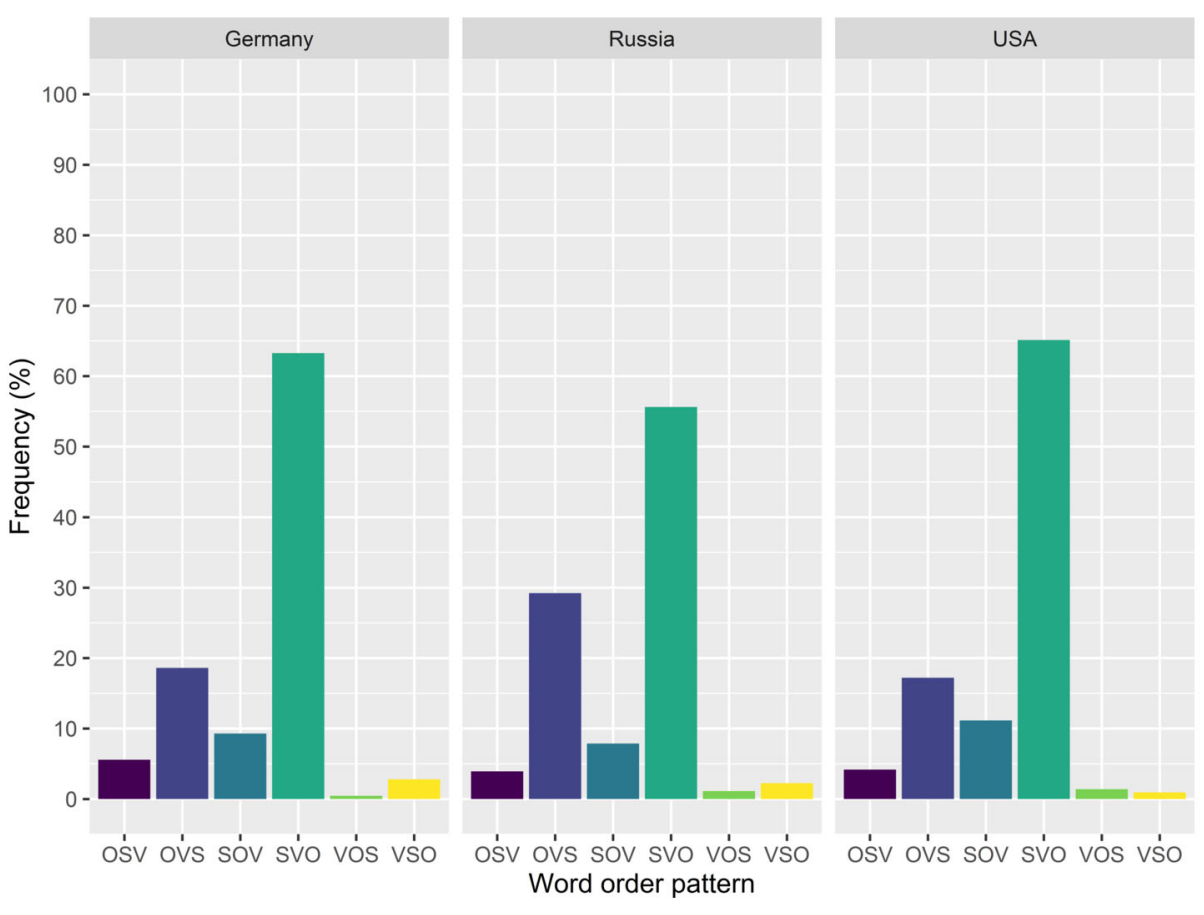

Fig. 3 Default word order patterns in main clauses

Table 8 Overall number of six default word order patterns in embedded clauses

\begin{tabular}{ll}
\hline Groups & Number of finite clauses \\
\hline HSs_US & 53 \\
HSs_Germany & 88 \\
Monolinguals & 34 \\
\hline
\end{tabular}

clauses). Monolingual speakers showed a clearer increase of SVO in embedded clauses than HSs in Germany (61,8\% in embedded clauses vs. 55,6\% in main clauses). HSs in the US almost did not produce any other word orders in embedded clauses except for the SVO (90,6\% in embedded clauses vs. $65,1 \%$ in main clauses).

The overall distribution of different word orders was found to be similar between HSs in Germany and monolingual speakers while it significantly differed between HSs of the two groups $\left(X^{2}(1, \mathrm{~N}=141)=11.57, p=.00067\right)$ and between HSs in the US and monolinguals $\left(X^{2}(1, \mathrm{~N}=87)=10.47, p=.001\right) .^{7}$ As for the verb-final word orders, (i.e., SOV and OSV grouped together) their distribution was similar between HSs in Germany and monolingual speakers. ${ }^{8}$

\footnotetext{
${ }^{7}$ The overall distribution of different word orders could only be made between SVO and all non-SVO orders since HSs in the US overall had only five instances of different non-SVO orders.

${ }^{8}$ No comparison with HSs in the US was possible due to the small number of occurrences of verb-final word orders in embedded clauses.
} 


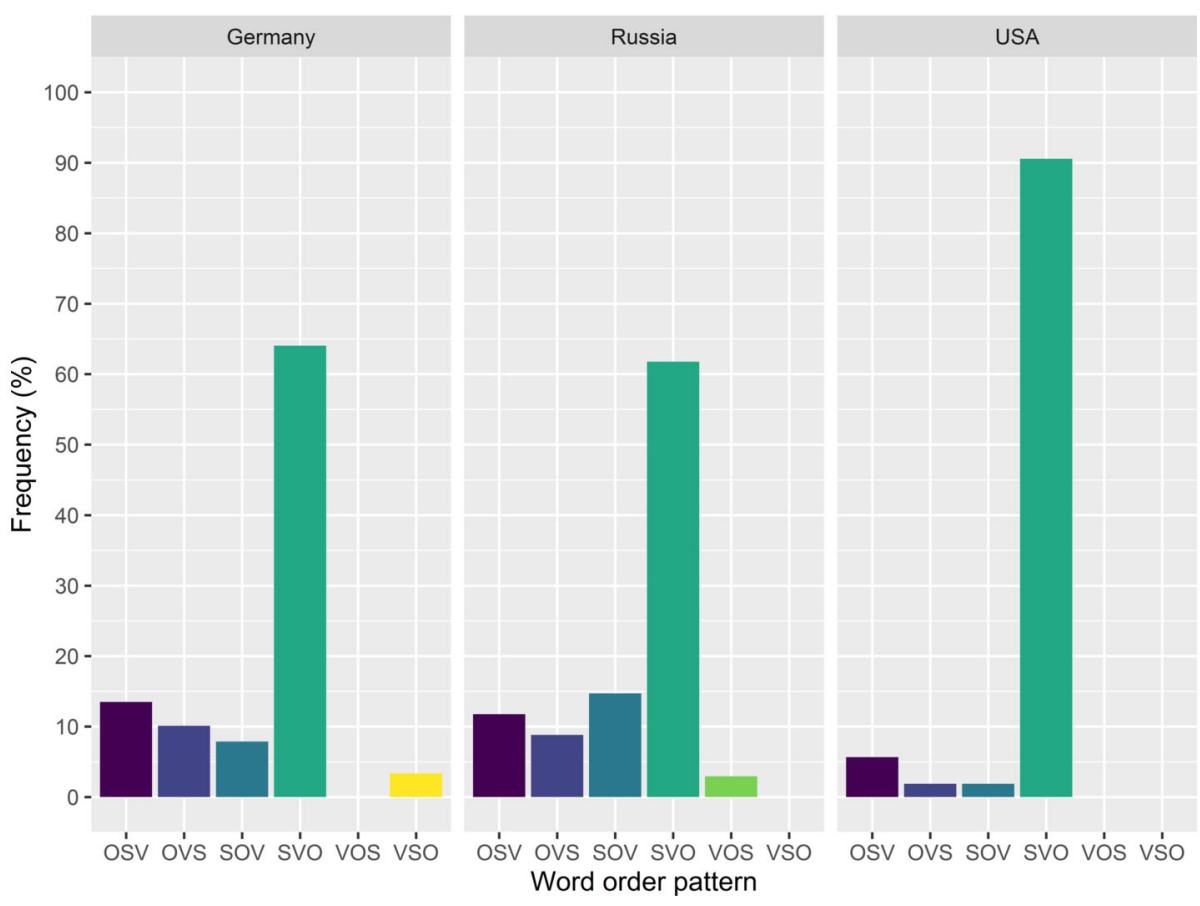

Fig. 4 Default word order patterns in embedded clauses

To sum up, HSs in Germany behaved similarly to the monolingual speakers regarding their word order patterns in both main and embedded clauses. HSs in the US were similar to two other speaker groups in the main clauses, but they differed from the monolingual speakers and HSs in Germany in the embedded clauses by predominantly producing SVO word order.

\section{Discussion}

The current study investigated the word order patterns produced by HSs of Russian residing in the US and Germany as well as by monolingual speakers of Russian using a corpus of semi-spontaneous spoken and written narratives. The goal of this paper was to answer the following research question:

RQ: Are the word order patterns produced by HSs of Russian residing in the US and Germany different from those of monolingual speakers of Russian?

Our results refute Prediction 1, which stated that HSs in Germany would differ from monolinguals regarding the overall word order patterns by producing more V-final linearizations in both main and embedded clauses. We found that HSs in Germany behaved similarly to monolinguals regarding the distribution of all word order patterns (V-final and all other word order patterns separately) in the overall dataset as well as in main and embedded clauses separately. Since our results on V-final orders differ from those of Brehmer and Usanova 
(2015), we will elaborate on this with regard to the differences in the experimental set-up, speaker populations and data analysis.

The written production data elicited by Brehmer and Usanova (2015) included two texts with register differentiation: "Fast Catch Boomerang" and "Boomerang in the park". In the following we will elaborate on the task "Fast Catch Boomerang", since we think this task may have had implications for the results of their study. The "Fast Catch Boomerang" task aimed at eliciting texts in which participants had to explain how to construct a boomerang. In order to write such a text one needs to have knowledge of the academic and technical vocabulary as well as be aware of narrative techniques used in such texts. Thus, such type of text may have been new for the HSs (cf. Reich et al., 2009) and as a result they produced innovations regarding the word order patterns that were sometimes inappropriate with respect to the information structure.

Moreover, differences in the annotation and data analysis may have also contributed to the differences in results between Brehmer and Usanova (2015) and this study. In contrast to the present study, Brehmer and Usanova (2015) included patterns with omitted subjects into the analysis and also annotated the verb placement in relation to the overt subject and direct object irrespective of further clausal constituents such as indirect objects and adverbial modifiers. Consequently, the word order patterns discussed in Brehmer and Usanova (2015) and in this study are presumably not equivalent. For example, SOV order in Brehmer and Usanova (2015) study may include word order combinations such as OoblSOV, SOoblOV, SOVOobl (and possibly other patterns), which were not included in the present analysis.

As for the HSs in the US, our results generally confirm Prediction 2, which stated that HSs in the US would differ from monolinguals regarding the overall word order patterns by producing more SVO orders. HSs in the US differed from monolingual speakers regarding the distribution of SVO word orders in the overall data sample as well as in embedded clauses separately. In embedded clauses, HSs in the US differed not only from the monolingual speakers, but also from the HSs in Germany by producing significantly more SVO orders. Generally, SVO word order was nearly the only word order produced by HSs in the US in embedded clauses $(90,6 \%$ of all word orders). Interestingly, differences in SVO frequency between HSs in the US and monolingual speakers are apparent in embedded clauses, but not in main clauses. In main clauses, HSs in the US and monolinguals showed similar distribution of different word order patterns.

How can we explain such an increase of SVO word orders by the HSs of Russian in the US? On the one hand, the results of HSs in the US can point to transfer from English, since English is a strict SVO language with few reordering options. Such explanation is, however, not entirely plausible since HSs in the US differed from monolinguals in the embedded clauses, but not in the main clauses. If the data had not been split into different clause types, we might have speculatively concluded that transfer was at play. However, now it is obvious that transfer cannot fully account for the results of the study.

On the other hand, the increased frequency of SVO by HSs in the US might be explained by the strategy that is called "narrowing of options" (Heine, 2006). This is a strategy of choosing one word order from many available under language contact. According to Heine (2006, p. 4):

"One way of replicating a word order arrangement found in another language is by narrowing down the range of discourse options available by choosing among the patterns that are available in the replica language the one that most readily corresponds to the one in the model language and making it the regular one - using it more frequently and in a wider range of contexts." 
Thus, "narrowing of options" means that HSs have more possible word order combinations in their HL (i.e., SVO, OVS, SOV, OSV, VSO, VOS) than in their ML (i.e., SVO) and they select one word order combination that is basic in both English and Russian (i.e., $\mathrm{SVO}$ ) and expand its use to a wider range of contexts. However, it remains to be explained why such strategy was only applied to the embedded clauses, but not to the main ones. Besides, Heine's version of "narrowing of options" still involves an aspect of transfer.

Let's try to see how main and embedded clauses differ from each other. Embedded clauses were reported to have a less varied word order compared to main clauses. Bybee (2002, p. 14) reports that the main changes of word order are more likely to occur in main clauses than in subordinate clauses since "main clauses are pragmatically richer, containing the focused information and the possibility of setting off old from new information, while subordinate clauses tend to be pragmatically more even, replaying previously presented or supplementary material". For Russian, it was stated that the word order in embedded clauses might be less varied compared to the main clauses due to the differences of two clause types regarding their discourse structure (Bailyn, 2012, p. 84). However, the exact differences in discourse structure are not specified by Bailyn (2012).

Our results support the statement by Bailyn (2012) about the less varied word order patterns in embedded clauses compared to main clauses. Monolingual speakers produced more word order patterns in main (six patterns) than in embedded clauses (five patterns). Besides, the frequency of the basic SVO order increased in embedded clauses $(61,8 \%)$ compared to the main clauses $(55,6 \%)$. HSs in Germany showed results similar to monolinguals, i.e., they produced six word order patterns in main clauses and five word order patterns in embedded clauses. Moreover, HSs in Germany showed a slight increase in SVO frequency in embedded clauses $(65,2 \%)$ compared to the main clauses $(63,3 \%)$. HSs in the US also showed less varied word order patterns in embedded clauses (four patterns) than in main clauses (six patterns) and the increase of the SVO order in embedded clauses $(90,6 \%)$ was substantial compared to the main clauses $(65,1 \%)$.

Despite the general observation that all speaker groups produced less varied word orders in embedded clauses and more SVO utterances, it remains to be explained why exactly HSs in the US produced predominantly SVO patterns.

Embedded clauses are often regarded to be an indicator of syntactic complexity (Sánchez Abchi \& De Mier, 2017, for heritage Spanish; Levy et al., 2013, for relative clauses in monolingual Russian; Lintunen \& Mäkilä, 2014, for L2 English by Finnish monolingual speakers). Besides, the processing of embedded clauses was found to be less accurate than the processing of main clauses (e.g., Baker \& Wagner, 1987; Sanford, 2002). Furthermore, embedded clauses are usually acquired later than main and coordinate clauses (Kuiken \& Vedder, 2019, for L2 acquisition; Cejtlin, 2000, pp. 209-220, on acquisition of syntax by monolingual Russian-speaking children; Ovčinnikova, 2011, on monolingual Russian and heritage Russian in Israel; Čirševa, 2011, on Russian-English simultaneous bilinguals). It is possible that the generally higher complexity of embedded clauses led to the increased use of SVO by HSs.

In order to explain the results of the HSs in the US in embedded clauses, we additionally annotated them for different clause types. We expected that HSs in the US would predominantly produce one type of embedded clauses, i.e., relative clauses. Relative clauses are particularly interesting in terms of word order, since they are restricted in their word order options in Standard Russian by typically being either SVO or OVS. Contrary to our expectations, HSs in the US produced not only relative clauses $(50 \%)$, but also temporal $(37,5 \%)$, 
some argument $(6,25 \%)$ and causal $(4,17 \%)$ clauses as well as one final $(2,08 \%)$ embedded clause with the SVO order (see Fig. 5 in Appendix). Therefore, it seems that SVO is not bound to a particular type of an embedded clause for HSs in the US, but represents rather a more general tendency.

To sum up, the increase of SVO word order by the HSs in the US is attested in the embedded clauses, but not in the main clauses. Apparently, clause type seems to be a major factor driving the increase of SVO order in productions of HSs in the US, and this factor needs to be investigated on a larger data sample. Such increase can be motivated by the differences in information structure between the main and embedded clauses as well as the general complexity of embedded clauses. Both the "narrowing of options" in the classical sense and transfer are problematic for the explanation of the results, since both do not readily allow for a distinction between main and embedded clauses. One could think of a modified version of "narrowing of options" in which the choice of word order options is narrowed under peculiar conditions of information structure and complexity. This narrowing scenario may be further facilitated by a specific language-contact situation including extralinguistic factors. In our case, HSs in the US probably differ from the HSs in Germany with respect to a whole set of extra-linguistic factors, e.g., the intensity of contact between members of the linguistic community. These factors, however, are to be investigated in further research.

Next to the main RQ, we have checked the data for other factors, such as communicative situations and language performance since these factors were included in the study design. Additionally, information structure was touched upon, although not in a great detail, since it was not in the focus of the current study and would require additional extensive manual annotations. In what follows, we address each of these factors in turn.

As for different communicative situations (i.e., formality and mode), the in-group comparison revealed no effect of formality across all three speaker groups. The effect of mode was only found in productions of HSs in the US, but not in productions of HSs in Germany and monolingual speakers. Specifically, HSs in the US produced significantly more SVO orders in written situations compared to spoken ones $\left(X^{2}(1, \mathrm{~N}=268)=4.08, p=.043\right)$ (see Figs. 6 and 7 in Appendix). In order to see a clearer effect of mode and an effect of formality one needs to look at a greater data sample.

Regarding the language performance, we were interested whether the number of innovations produced by all speaker groups in the domain of morphology and lexicon correlated with the word order. We expected that those speakers who had a higher innovation score would produce less variations of different word orders and more SVO orders than those speakers who had a lower innovation score in the domain of morphology and lexicon (see Sussex, 2002; Polinsky, 2011). The results, however, showed no correlation between the language performance and the word order variation as well as the proportion of basic SVO word orders according to the Spearman's Rank-Order Correlation coefficient (see Figs. 8 and 9 in Appendix). This means that other (possibly meta linguistic) factors contributed to the production of different word order patterns and the proportion of SVO orders.

The frequent SVO order produced by HSs in the US in the overall dataset as well as in the embedded clauses can have implications for information structure. Information structure is an important factor that governs a particular word order choice in both main and embedded clauses in Standard Russian. HSs in the US might have disregarded this aspect. First, the reason for this assumption comes from other studies reporting that word order in heritage Russian does not always correspond to the requirements of infor- 
mation structure (e.g., Laleko \& Dubinina, 2018; Brehmer \& Usanova, 2015, have some indications in their data). Second, although the word order combinations in our data were not systematically checked for contextual appropriateness, some SVO orders produced by HSs in the US attracted our attention since they did not adhere to the requirements of information structure in the given contexts. Take a look at the following example:

$$
\begin{aligned}
& \text { Context: Ja tol'ko čto uvidela avariju v pod'ezde }{ }^{9} \\
& \text { 'I just saw an accident in a porch'. }
\end{aligned}
$$

$$
\begin{aligned}
& \text { Target: Dve mašiny v'exali v pod'ezd } \\
& \text { two cars drove into porch } \\
& \mathrm{S}_{\text {new }} \mathrm{V} \text { Oobl } 1_{\text {given }} \\
& \text { 'Two cars drove into the porch' } \\
& \text { cf. I v pod"ezd v"exali dve mašiny }{ }^{10} \\
& \text { Oobl }_{\text {given }} \mathrm{V} \quad \mathrm{S}_{\text {new }}
\end{aligned}
$$

(USbi66FR_iwR)

In the example (8) above two cars is a newly introduced referent while the car has been mentioned before. In Standard Russian, new referents are expected to appear clausefinally and the typical order of referents is "given-before-new", i.e., referents that were already mentioned appear before the ones that were introduced for the first time (e.g., Slioussar, 2011; Luchkina \& Cole, 2016). In the example (9) the order of referents is unusual, i.e., a new referent precedes the given one. In Standard Russian, one would need to change the word order to the OoblVS to express the information status of referents.

As for the HSs in Germany, they behaved similarly to the monolingual speakers which may be facilitated by the fact that German also allows for word order flexibility, i.e., word order is governed not only by syntactic factors (e.g., the position of the finite verb), but also by the requirements of information structure. In monolingual Russian, word order is mainly governed by information structure and not by syntactic factors (Brehmer \& Usanova, 2015, p. 162, citing Gladrow, 1998, p. 200). The fact that HS in Germany, but not HSs in the US, performed similar to monolinguals may be due to the more flexible word order in monolingual German compared to monolingual English.

However, it is worth mentioning that although HSs in Germany show similar frequency of different word orders to that of monolingual speakers, some of the constituent orders produced by HSs do not adhere to the intended information structure. This can be seen in the following examples:

(9) Context: sej mjač pokatil'sja po doroge. Potom soboka potnjalus' k mjaču k centru dorogi $i^{11}$

'This ball rolled down the road. Then a dog reached for the ball towards the center of the road'.

\footnotetext{
${ }^{9}$ Here and further the original orthography of the speaker is preserved. The speaker did not use the hard sign, but the soft sign in her text.

${ }^{10}$ It is not entirely clear why the speaker mentioned the "porch" since it was not shown on the video. Probably the speaker meant 'the parking lot' (parkovka).
} 


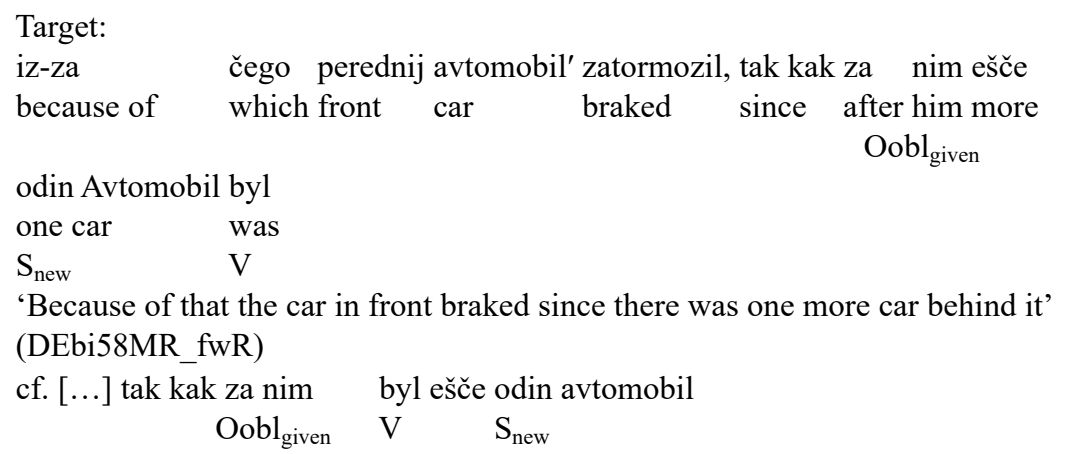

In example (9) one more car is a new referent and is expected to be placed clause-finally. Moreover, the verb placed at the right edge of the clause gives an impression of the verb being focused contrary to the context.

(10) Context: 28-go marta v 16:00 mašina 1 v"exala v mašinu 2. Èto proizošlo potomu-čto sobaka pobežala na dorogu.

On March 28 at 16:00, a car number 1 bumped into a car number 2. It happened because a dog ran onto the road.

Target: posle togo kak pokotilsja futbol'nyj mjač na ètuže dorogu ${ }^{12}$ after that how rolled soccer ball on same road $\mathrm{V} \quad \mathrm{S}_{\text {new }}$ Oobl $_{\text {given }}$

'After a soccer ball rolled down the same road' cf. posle togo, kak na ètu že dorogu pokatilsja futbol'nyj mjač (DEbi77MR_fwR)

In example (10) the order of referents is "new-given" since a ball was just introduced into the story while the road was previously mentioned. Besides, verb and subject are a part of the new information focus and would be both typically placed after the oblique object.

Although HSs in Germany did not differ from monolingual speakers quantitatively regarding the different word orders they may still differ from monolinguals qualitatively, i.e., it is not clear whether all word order combinations produced by HSs in Germany reflect the required information structure and examples like (9) and (10) demonstrate that this indeed was not always the case. Thus, the next step would be to qualitatively check all word order combinations produced by HSs of both groups with respect to their contextual felicitousness.

\section{Conclusion}

In conclusion, the current study showed that HSs with different majority languages behaved differently regarding the distribution of word order patterns in Russian. HSs in Germany were found to be similar to monolingual speakers while HSs in the US differed from monolinguals by producing more SVO order and less OVS order in the overall dataset.

\footnotetext{
${ }^{11}$ The original orthography of the speaker is preserved. Here the order of referents is also unusual, i.e., newbefore-given. The expected word order is OoblVS.

${ }^{12}$ The original orthography of the speaker is preserved.
} 
The split of the data into main and embedded clauses revealed further interesting findings. Specifically, HSs in the US differed from both monolinguals and HSs in Germany by producing more SVO orders in embedded clauses, but not in main clauses. Thus, the clause type as well as the majority language of HSs seem to be important factors for the production of different word order patterns in heritage Russian.

All in all, the present study contributed to the understanding of possible reasons behind the restructuring mechanisms that may drive word order change for HSs of Russian in the US. We have discussed whether the increase of SVO orders by HSs in the US can be attributed to transfer from the ML or to the strategy "narrowing of options". Since the increase of the SVO order was only found in embedded clauses, but not in main clauses, it leads us to conclude that the clause type may be an important factor that drives word order change in productions of HSs. Summing up, it became apparent that neither transfer nor the classical "narrowing of options" alone can explain the results of the study. Instead, the increase of SVO order in embedded clauses by HSs in the US might be rather a result of a combination of a decrease of word order options in embedded clauses observed in all groups and general effects of language contact, including extra-linguistic factors.

\section{Appendix}

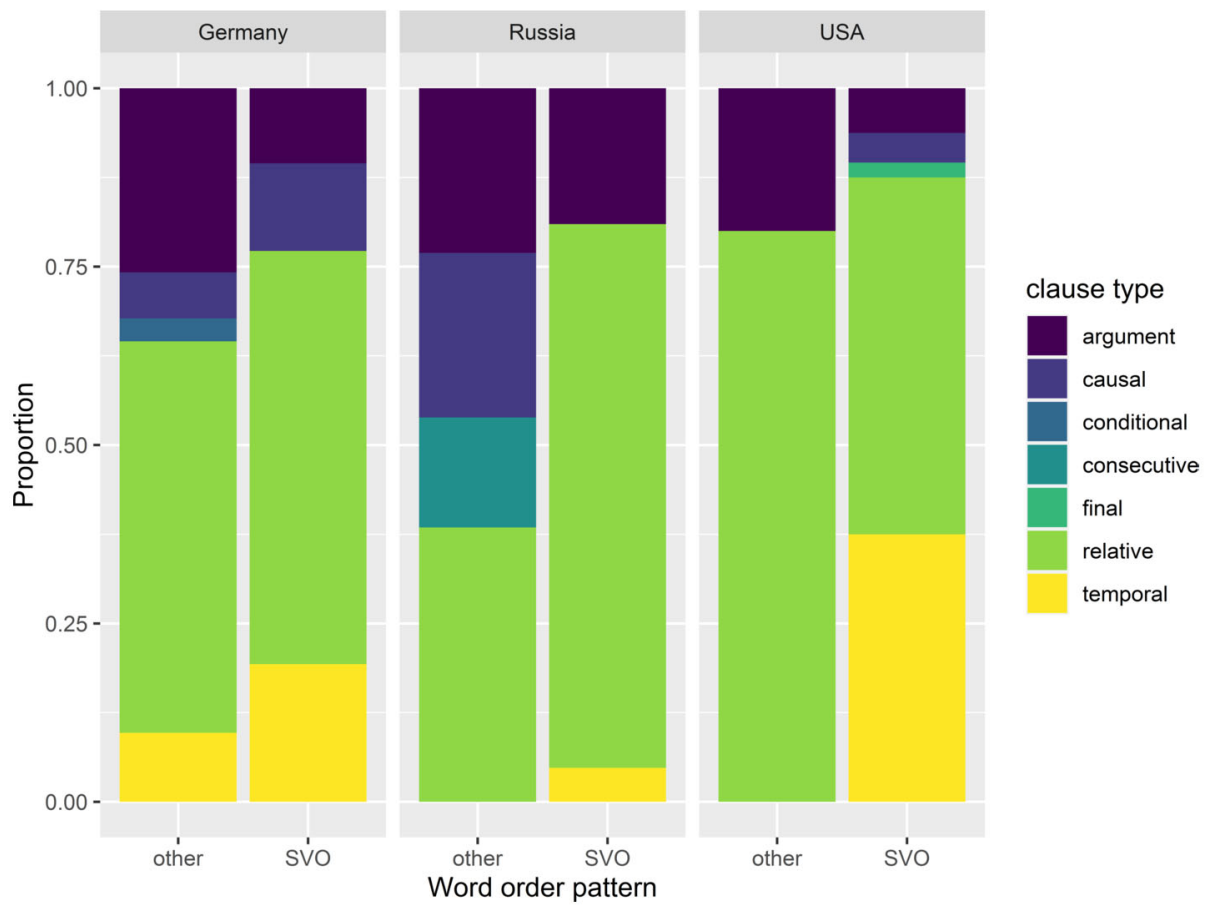

Fig. 5 Types of embedded clauses across three speaker groups 


\section{Formal situations, relative numbers (\%)}
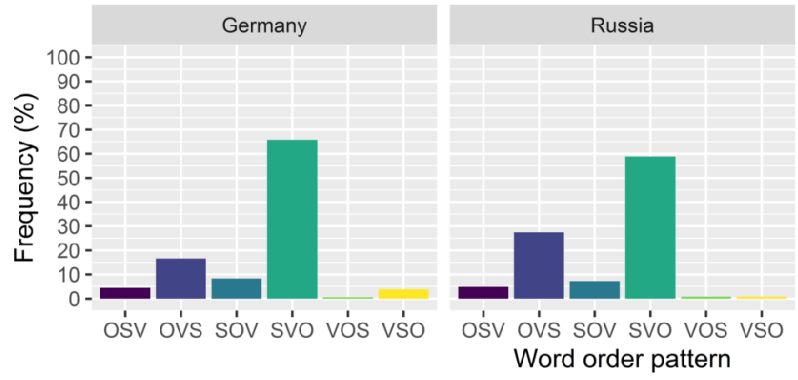

Informal situations, relative numbers (\%)
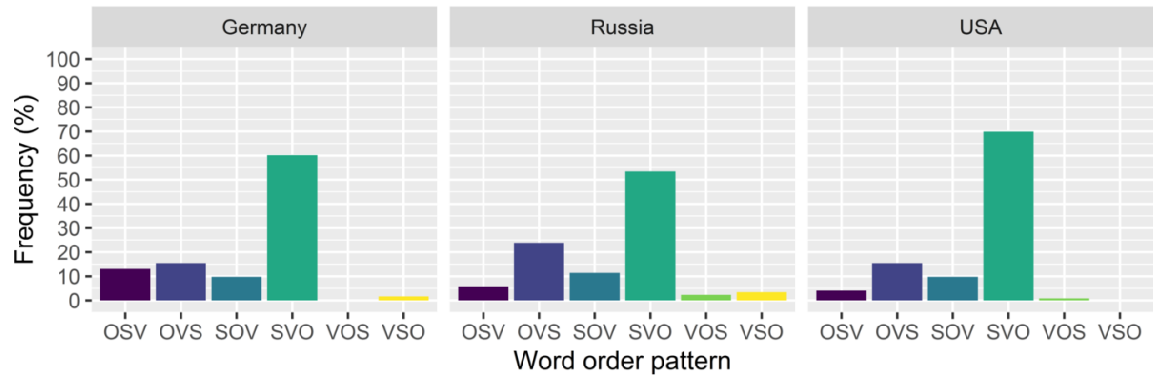

Fig. 6 Word orders in formal and informal situations

Spoken mode, relative numbers (\%)
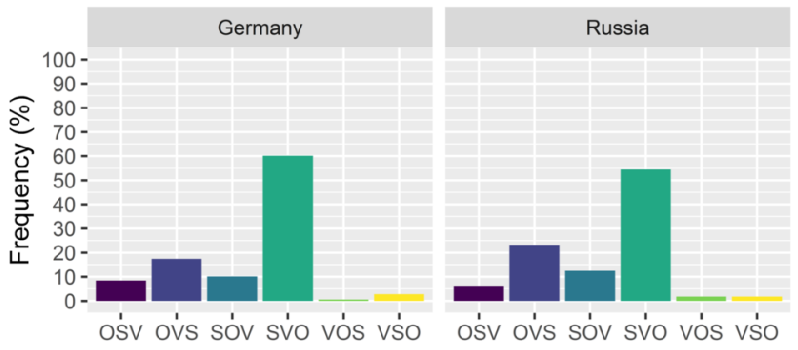

ośv óvs sóv svio vós vśo Word order pattern

Written mode, relative numbers (\%)
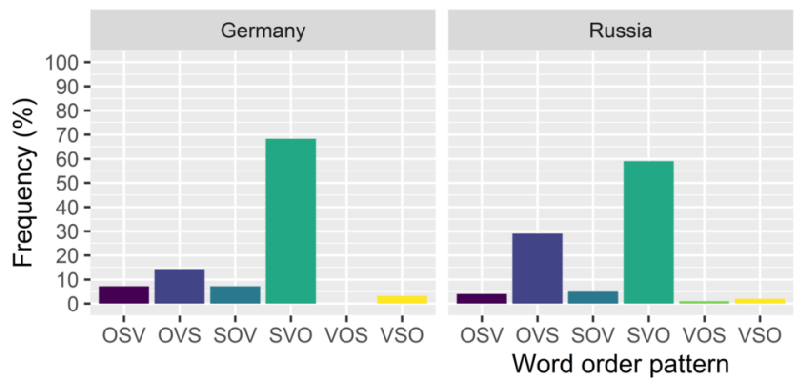

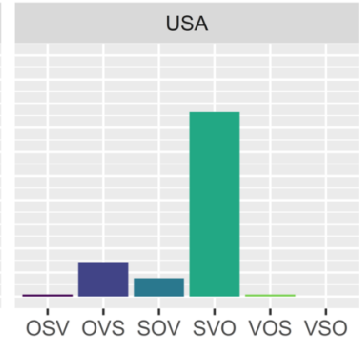

ó̉ ớs sóv svio vós v'́o USA

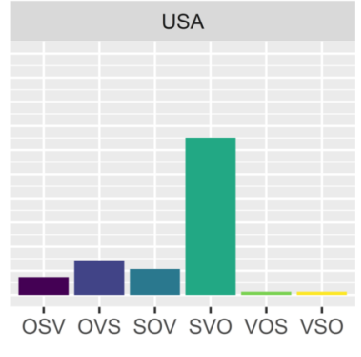

ośv ớs sóv svio vós vśo

Fig. 7 Word orders in different modes 


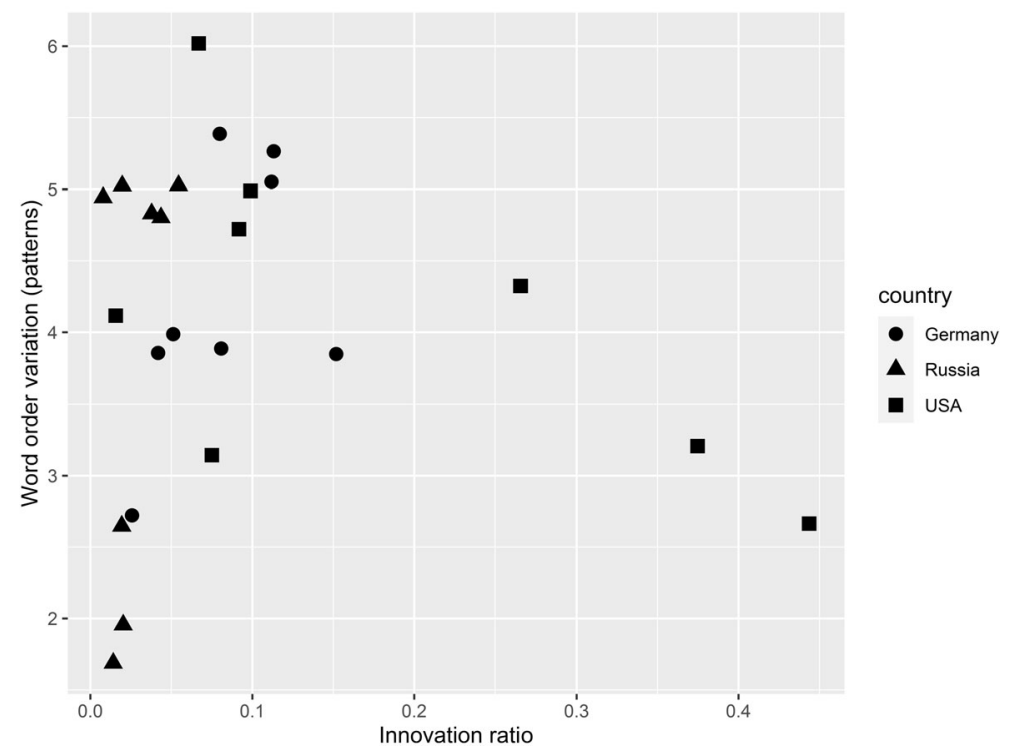

Fig. 8 Innovation ratio and word order variation

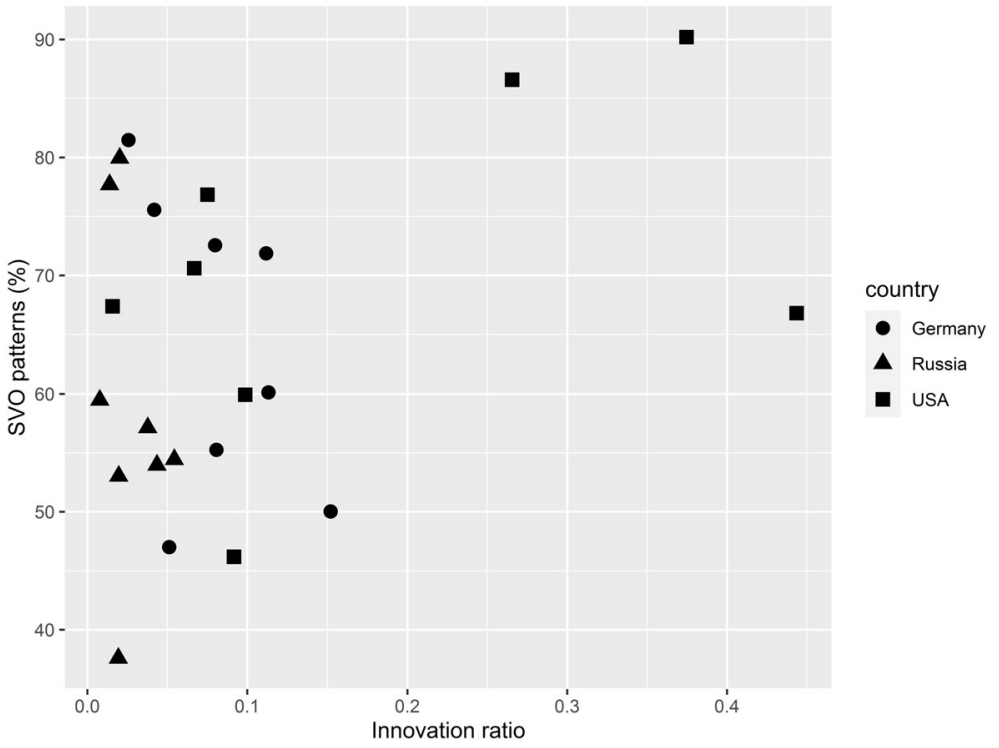

Fig. 9 Innovation ratio and SVO proportion

Acknowledgements This research was funded by a grant from the Deutsche Forschungsgemeinschaft (DFG, German Research Foundation) to the Research Unit "Emerging Grammars in Language Contact Situations: A Comparative Approach" (FOR 2537), in projects P3 (project no. 39482131, GZ SZ 263/4-1, PIs: Luka Szucsich and Natalia Gagarina) and P7 (project no. 394844953, GZ ZE 940/2-1, PI: Sabine Zerbian).

Funding Note Open Access funding enabled and organized by Projekt DEAL. 
Data Availability All data presented in this publication were drawn from the RUEG corpus, available in open access: https://doi.org/10.5281/zenodo.3236068.

Materials Availability All materials used for the data collection are available in open access: https://osf.io/ qhupg/. Extra materials are available upon request.

Code Availability For the data processing MS Excel, R and RStudio were used. R code is available upon request.

\section{Declarations}

Conflict of Interest / Competing interests The authors have no competing financial or non-financial interests to declare.

Ethics approval DFG Ethic Approval to "Emerging Grammars in Language-Contact Situations (RUEG)" (PI: H. Wiese) was obtained on 20.11.2017.

Consent to participate Informed consent was obtained from all individual participants included in the study.

Consent for publication All individual participants gave permission for their data for scientific publication.

Open Access This article is licensed under a Creative Commons Attribution 4.0 International License, which permits use, sharing, adaptation, distribution and reproduction in any medium or format, as long as you give appropriate credit to the original author(s) and the source, provide a link to the Creative Commons licence, and indicate if changes were made. The images or other third party material in this article are included in the article's Creative Commons licence, unless indicated otherwise in a credit line to the material. If material is not included in the article's Creative Commons licence and your intended use is not permitted by statutory regulation or exceeds the permitted use, you will need to obtain permission directly from the copyright holder. To view a copy of this licence, visit http://creativecommons.org/licenses/by/4.0/.

\section{References}

Albirini, A., Benmamoun, E., \& Saadah, E. (2011). Grammatical features of Egyptian and Palestinian heritage speakers' oral production. Studies in Second Language Acquisition, 33(2), 273-303. http://www.jstor. org/stable/44486004.

Anstatt, T. (2008). Aspect and tense in storytelling by Russian, German and bilingual children. Russian Linguistics, 32(1), 1-26. https://doi.org/10.1007/s11185-007-9021-0.

Bailyn, J. F. (2002). Inversion, dislocation and optionality in Russian. In G. Zybatow, U. Junghanns, G. Mehlhorn, \& L. Szucsich (Eds.), Current issues in formal Slavic linguistics (pp. 280-293). Frankfurt: Peter Lang.

Bailyn, J. F. (2004). Generalized inversion. Natural Language and Linguistic Theory, 22, 1-49.

Bailyn, J. F. (2012). Syntax of Russian. Cambridge: Cambridge University Press.

Baker, L., \& Wagner, J. L. (1987). Evaluating information for truthfulness: the effects of logical subordination. Memory \& Cognition, 15, 247-255. https://doi.org/10.3758/BF03197723.

Benmamoun, E., Montrul, S., \& Polinsky, M. (2013). Heritage languages and their speakers: opportunities and challenges for linguistics. Theoretical Linguistics, 39, 129-181. https://doi.org/10.1515/tl-2013-0009.

Berman, R. A. \& Slobin, D. I. (Eds.) (1994). Relating events in narrative: a crosslinguistic developmental study. Hillsdale: Lawrence Erlbaum.

Brehmer, B. (2007). Sprechen Sie Qwelja? Formen und Folgen russischdeutscher Zweisprachigkeit in Deutschland. In T. Anstatt (Ed.), Mehrsprachigkeit bei Kindern und Erwachsenen. Erwerb, Formen, Förderung (pp. 163-186). Tübingen: Attempto Verlag.

Brehmer, B., \& Usanova, I. (2015). Let's fix it? Cross-linguistic influence in word order patterns of Russian heritage speakers in Germany. In H. Peukert (Ed.), Transfer effects in multilingual language development (pp. 161-188). https://doi.org/10.1075/hsld.4.08bre. Amsterdam: John Benjamins.

Bybee, J. (2002). Main clauses are innovative, subordinate clauses are conservative consequences for the nature of constructions. In J. Bybee \& M. Noonan (Eds.), Complex sentences in grammar and discourse: essays in honor of Sandra A. Thompson. (pp. 1-17). https://doi.org/10.1075/z.110.02byb. Amsterdam: John Benjamins. 
Cejtlin, S. (2000). Jazyk i rebenok: Lingvistika detskoj reči: Učeb. Posobie dlja stud. vyš̌. učeb, zavedenij [Language and the child: linguistics of children's speech: a study guide for university students]. Moscow: VLADOS.

Chafe, W. L. (1976). Givenness, contrastiveness, definiteness, subjects, topics and point of view. In N. Li Charles (Ed.), Subject and topic (pp. 27-55). New York: Academic Press.

Cuza, A. (2012). Crosslinguistic influence at the syntax proper: interrogative subject-verb inversion in heritage Spanish. International Journal of Bilingualism, 17, 71-96. https://doi.org/10.1177/ 1367006911432619.

Čirševa, G. (2011). Osobennosti odnovremennogo usvoenija russkoj i anglijskoj grammatiki [Features of simultaneous acquisition of Russian and English grammar]. In S. Cejtlin \& M. B. Eliseeva (Eds.), Put'v jazyk: Odnojazyčie i dvujazyčie [Monolingual and bilingual path to language] (pp. 202-219). Moscow: Jazyki slavjanskix kul'tu.

De Vogelaer, G. (2007). Extending Hawkins' comparative typology: case, word order, and verb agreement in the Germanic languages. Nordllyd, 34, 167-182. http://hdl.handle.net/1854/LU-362994.

Dubinina, I., \& Polinsky, M. (2013). Russian in the USA. In M. Moser \& M. Polinsky (Eds.), Slavic languages in migration. Münster: Lit Verlag. https://www.lit-verlag.de/isbn/978-3-643-90328-0.

Eppler, E. (1999). Word order in German-English mixed discourse. Working Papers in Linguistics, 11, $285-308$.

Fenyvesi, A. (2005). Hungarian in the United States. In A. Fenyvesi (Ed.), Hungarian language contact outside Hungary: studies on Hungarian as a minority language (pp. 265-318). Amsterdam: John Benjamins.

Gagarina, N. (2011). Acquisition and loss of 11 in a Russian-German bilingual child: a case study. In S. Cejtlin (Ed.), Monolingual and bilingual path to language (pp. 137-163). Moscow: Jazyki slavjanskix kul'tur.

Gagarina, N., Martynova, M., Sekerina, I., \& Szucsich, L. (2020). From first verbs to adulthood: Aspect in heritage Russian in the US and Germany. In E. V. Golovko, E. V. Gorbova, P. A. Kočarov, V. S. Xrakovskij, \& O. Ju. Čujkova (Eds.), Vzaimodejstvie aspekta so smežnymi kategorijami. Materialy VII Meždunarodnoj konferencii Komissii Po aspektologii Meždunarodnogo komiteta slavistov. [Aspect interaction with related categories. Proceedings of the VII International Conference of the Commission on Aspectology of the International Committee of Slavic Studies] (pp. 112-117). St. Petersburg: RGPU im. A. I. Gercena.

Gärtner, H. M. (2000). Are there V2 relative clauses in German? Journal of Comparative Germanic Linguistics, 3, 97-141. https://doi.org/10.1023/A:1011432819119.

Gladrow, W. (Ed.) (1998). Russisch im Spiegel des Deutschen: Eine Einführung in den russisch-deutschen und deutsch-russischen Sprachvergleich. Oxford: Peter Lang.

Guijarro-Fuentes, P., \& Schmitz, K. (2015). The nature and nurture of heritage language acquisition. Lingua, 164(B), 239-250. https://doi.org/10.1016/j.lingua.2015.05.008.

Heine, B. (2006). Contact-induced word order change without word order change. Working Papers in Multilingualism, 76, 1-24.

Isurin, L. (2005). ISB4: cross linguistic transfer in word order: evidence from L1 forgetting and L2 acquisition. In J. Cohen, K. T. McAlister, K. Rolstad, \& J. MacSwan (Eds.), Proceedings of the 4th international symposium on bilingualism (pp. 1115-1130). Somerville: Cascadilla Press.

Isurin, L., \& Ivanova-Sullivan, T. (2008). Lost in between: the case of Russian heritage speakers. Heritage Language Journal, 6(1), 72-104. https://doi.org/10.46538/hlj.6.1.4.

Isurin, L. (2011). Russian diaspora. De Gruyter Mouton.

Johannessen, J. B., \& Laake, S. (2015). On two myths of the Norwegian language in America: Is it oldfashioned? Is it approaching the written Bokmål standard? In J. B. Johannessen \& J. C. Salmons (Eds.), Germanic heritage languages in North America (pp. 299-322), Amsterdam: John Benjamins.

Junghanns, U., \& Zybatow, G. (2007). Syntax and information structure of Russian clauses. In W. E. Browne, E. Dornisch, N. Kondrashova, \& D. Zec (Eds.), Annual workshop on formal approaches to slavic linguistics. The Cornell Meeting, 1995 (pp. 289-319). Ann Arbor, Michigan: Michigan Slavic Publications.

Kallestinova, E. (2007). Aspects of word order in Russian. Doctoral dissertation, University of Iowa. Iowa research online. https://doi.org/10.17077/etd.11qhthvg.

Kempen, G., \& Harbusch, K. (2019). Mutual attraction between high-frequency verbs and clause types with finite verbs in early positions: corpus evidence from spoken English, Dutch, and German. Language, Cognition and Neuroscience, 34(9), 1140-1151. https://doi.org/10.1080/23273798.2019.1642498.

Klassert, A., Gagarina, N., \& Kauschke, C. (2014). Object and action naming in Russian and German-speaking monolingual and bilingual children. Bilingualism: Language and Cognition, 17, 73-88. https://doi.org/ $10.1017 /$ S1366728913000096.

Kisselev, O. (2019). Word order patterns in the writing of heritage and second language learners of Russian. Russian Language Journal, 69, 149-174. 
Krifka, M. (2007). Basic notions of information structure. In C. Fery, G. Fanselow, \& M. Krifka (Eds.), Interdisciplinary studies of information structure, Potsdam (Vol. 6, pp. 13-56).

Kuiken, F., \& Vedder, I. (2019). Syntactic complexity across proficiency and languages: L2 and L1 writing in Dutch, Italian and Spanish. International Journal of Applied Linguistics, 29(2), 192-210. https://doi. org/10.1111/ijal.12256.

Laleko, O. (2010). The syntax-pragmatics interface in language loss: covert restructuring of aspect in heritage Russian, Doctoral dissertation, University of Minnesota. University of Minnesota Digital Conservancy. https://hdl.handle.net/11299/92219.

Laleko, O. (2011). Restructuring of verbal aspect in heritage Russian: beyond lexicalization. International Journal of Language Studies, 5(3), 13-26.

Laleko, O. (2015). From privative to equipollent: incipient changes in the aspectual system of heritage Russian. In G. Zybatow, P. Biskup, M. Guhl, C. Hurtig, O. Mueller-Reichau, \& M. Yastrebova (Eds.), Slavic grammar from a formal perspective. (pp. 273-286). Frankfurt am Main: Peter Lang. https://doi.org/10. 3726/978-3-653-05335-7.

Laleko, O. (2018). What is difficult about grammatical gender? Evidence from heritage Russian. Journal of Language Contact, 11(2), 233-267. https://doi.org/10.1163/19552629-01102004.

Laleko, O. (2019). Resolving indeterminacy in gender agreement: comparing heritage speakers and 12 learners of Russian. Heritage Language Journal, 16(2), 151-182. https://doi.org/10.46538/hlj.16.2.3.

Laleko, O., \& Dubinina, I. (2018). Word order production in heritage Russian: perspectives from linguistics and pedagogy. In S. Bauckus \& S. Kresin (Eds.), Connecting across languages and cultures: a heritage language festschrift in honor of Olga Kagan (pp. 191-215). Bloomington, IN: Slavica.

Levy, R., Fedorenko, E., \& Gibson, E. (2013). The syntactic complexity of Russian relative clauses. Journal of Memory and Language, 69, 461-495. https://doi.org/10.1016/j.jml.2012.10.005.

Lintunen, P., \& Mäkilä, M. (2014). Measuring syntactic complexity in spoken and written learner language: comparing the incomparable? Research in Language, 12(4), 377-399. https://doi.org/10.1515/rela2015-0005.

Luchkina, T., \& Cole, J. (2016). Structural and referent-based effects on prosodic expression in Russian. Phonetica, 73, 279-313. https://doi.org/10.1159/000449104.

Mayer, M. (1969). Frog, where are you? New York, NY: Dial Books for Young Readers.

Mayer, M., \& Mayer, M. (1978). A boy, a dog, a frog and a friend. New York, NY: Dial Books for Young Readers.

Meng, K., \& Protassova, E. (2016). Deutsch und Russisch: Herkunftssprachen in russlanddeutschen Aussiedlerfamilien. IDS Publikationsserver. https://ids-pub.bsz-bw.de/frontdoor/index/index/docId/ 4615 .

Montrul, S. (2010a). Dominant language transfer in Spanish L2 learners and heritage speakers. Special issue of Second Language Research, 26(3), 293-925.

Montrul, S. (2010b). How similar are adult second language learners and Spanish heritage speakers? Spanish clitics and word order. Applied Psycholinguistics, 31(1), 167-207. https://doi.org/10.1017/ S014271640999021X.

Montrul, S. (2015). The acquisition of heritage languages. Cambridge: Cambridge University Press.

Montrul, S., Bhatt, R. \& Girju, R. (2015). Differential object marking in Spanish, Hindi and Romanian as heritage languages Language, 91(3), 1-47.

Ovčinnikova, I. (2011). O stanovlenii kategorii taksisa (na materiale povestvovanij doškol'nikov) [On the formation of the taxis category (based on the narratives of preschoolers)]. In S. Cejtlin \& M. B. Eliseeva (Eds.), Put' v jazyk: Odnojazyčie $i$ dvujazyčie [Monolingual and bilingual path to language] (pp. 122-134). Moscow: Jazyki slavjanskix kul'tur.

O’Grady, W., Kwak, H.-Y., Lee, O.-S., \& Lee, M. (2011). An emergentist perspective on heritage language acquisition. Studies in Second Language Acquisition, 33(2), 223-245. https://doi.org/10.1017/ S0272263110000744.

Polinsky, M. (2006). Incomplete acquisition: American Russian. Journal of Slavic Linguistics, 14, $191-262$.

Polinsky, M. (2008a). Gender under incomplete acquisition: heritage speakers' knowledge of noun categorization. Heritage Language Journal, 6(1), 40-71. https://doi.org/10.46538/hlj.6.1.3.

Polinsky, M. (2008b). Without aspect. In G. G. Corbett \& M. Noonan (Eds.), Case and grammatical relations (pp. 263-282). Amsterdam: John Benjamins.

Polinsky, M. (2011). Reanalysis in adult heritage language: a case for attrition. Studies in Second Language Acquisition, 33(2), 305-328. https://doi.org/10.1017/S027226311000077X.

Polinsky, M. (2015). Heritage languages and their speakers. Zeitschrift für Fremdsprachwissenschaft, 26(1), $7-27$.

Polinsky, M. (2018). Heritage languages and their speakers. Cambridge: Cambridge University Press.

Rakhilina, E., Vyrenkova, A., Mustakimova, E., Ladygina, A., \& Smirnov, I. (2016). Building a learner corpus for Russian. In Proceedings of the joint workshop on NLP for computer assisted language learning 
and NLP for language acquisition at SLTC, Umeå, W16-65 (pp. 66-75). http://aclweb.org/anthology/ W16-65.

R Core Team (2020). R: a language and environment for statistical computing. R Foundation for Statistical Computing. https://www.R-project.org/.

Reich, H., Roth, H.-J., \& Döll, M. (2009). Fast Catch Bumerang. Deutsche Sprachversion. Auswertungsbogen und Auswertungshinweise. In D. Lengyel, H. H. Reich, H.-J. Roth, \& M. Döll (Eds.), Von der Sprachdiagnose zur Sprachförderung (pp. 207-241). Münster: Waxmann.

Romanova, N. (2008). Mechanisms of verbal morphology processing in heritage speakers of Russian. Heritage Language Journal, 6(1), 105-126. https://doi.org/10.46538/hlj.6.1.5.

Rothman, J. (2009). Understanding the nature and outcomes of early bilingualism: romance languages as heritage languages. International Journal of Bilingualism, 13(2), 155-163. https://doi.org/10.1177/ 1367006909339814.

Sanford, A. J. (2002). Context, attention and depth of processing during interpretation. Mind \& Language, 17(1-2), 188-206. https://doi.org/10.1111/1468-0017.00195.

Sánchez Abchi, V., \& De Mier, V. (2017). Syntactic complexity in narratives written by Spanish heritage speakers. Vigo International Journal of Applied Linguistics, 14, 125-148.

Slioussar, N. (2007). Grammar and information structure. A study with reference to Russian. Doctoral dissertation, Utrecht University. LOT.

Slioussar, N. (2011). Processing of a free word order language: the role of syntax and context. Journal of Psycholinguistic Research, 40, 291-306. https://doi.org/10.1007/s10936-011-9171-5.

Song, M., O'Grady, W., Cho, S., \& Lee, M. (1997). The learning and teaching of Korean in community schools. In Y.-H. Kim (Ed.), Korean language in America (Vol. 2, pp. 111-127). American Association of Teachers of Korean.

Sussex, R. (2002). Slavonic languages in emigration. In B. Comrie \& G. G. Corbett (Eds.), The Slavonic languages (pp. 999-1036). London: Routledge.

Švedova, N. J. (2005). Russkaja grammatika [Russian grammar]. Moscow: Institut russkogo jazyka im. V.V. Vinogradova RAN.

Valdés, G. (2005). Bilingualism, heritage language learners, and SLA research: opportunities lost or seized? The Modern Language Journal, 89(3), 410-426.

Wegener, H. (1993). Weil - das hat schon seinen Grund. Zur Verbstellung in Kausalsätzen mit weil im gegenwärtigen Deutsch. Deutsche Sprache, 21, 289-305.

Weiss, D., \& Raxilina, E. (2002). Forgetting one's roots: Slavic and non-Slavic elements in possessive constructions of modern Russian. STUF, 55(2), 173-205.

Wiese, H. (2020). Language situations: a method for capturing variation within speakers' repertoires. In Y. Asahi (Ed.), Methods in dialectology XVI (pp. 105-117). Oxford: Peter Lang. https://doi.org/10.3726/ b17102.

Wiese, H., Alexiadou, A., Allen, S., Bunk, O., Gagarina, N., Iefremenko, K., Jahns, E., Klotz, M., Krause, T., Labrenz, A., Lüdeling, A., Martynova, M., Neuhaus, K., Pashkova, T., Rizou, V., Tracy, R., Schroeder, C., Szucsich, L., Tsehaye, W., Zerbian, S., \& Zuban, Y. (Eds.) (2019). RUEG Corpus (Version 0.3.0) [Data set]. Zenodo. https://doi.org/10.5281/zenodo.3236069.

Publisher's Note Springer Nature remains neutral with regard to jurisdictional claims in published maps and institutional affiliations. 